\title{
Reconstructing the duty of water: a study of emergent norms in socio-hydrology
}

\author{
J. L. Wescoat Jr. \\ Massachusetts Institute of Technology, Cambridge, Massachusetts, USA
}

Correspondence to: J. L. Wescoat Jr. (wescoat@mit.edu)

Received: 27 May 2013 - Published in Hydrol. Earth Syst. Sci. Discuss.: 14 June 2013

Revised: 29 September 2013 - Accepted: 27 October 2013 - Published: 3 December 2013

\begin{abstract}
This paper assesses the changing norms of water use known as the duty of water. It is a case study in historical socio-hydrology, or more precisely the history of socio-hydrologic ideas, a line of research that is useful for interpreting and anticipating changing social values with respect to water. The duty of water is currently defined as the amount of water reasonably required to irrigate a substantial crop with careful management and without waste on a given tract of land. The historical section of the paper traces this concept back to late 18th century analysis of steam engine efficiencies for mine dewatering in Britain. A half-century later, British irrigation engineers fundamentally altered the concept of duty to plan large-scale canal irrigation systems in northern India at an average duty of 218 acres per cubic foot per second (cfs). They justified this extensive irrigation standard (i.e., low water application rate over large areas) with a suite of social values that linked famine prevention with revenue generation and territorial control. The duty of water concept in this context articulated a form of political power, as did related irrigation engineering concepts such as "command" and "regime." Several decades later irrigation engineers in the western US adapted the duty of water concept to a different socio-hydrologic system and norms, using it to establish minimum standards for private water rights appropriation (e.g., only 40 to 80 acres per cfs). While both concepts of duty addressed socio-economic values associated with irrigation, the western US linked duty with justifications for, and limits of, water ownership. The final sections show that while the duty of water concept has been eclipsed in practice by other measures, standards, and values of water use efficiency, it has continuing relevance for examining ethical duties and for anticipating, if not predicting, emerging social values with respect to water.
\end{abstract}

\section{Problem statement}

In a doctoral qualifying exam, a senior faculty member asked the candidate to discuss the duty of water concept in irrigation, to which the candidate briefly replied that while it had been an important standard for application rates in the early 20th century, it had been replaced by more precise standards of water use efficiency. While accurate, my answer at that time stopped short of considering how and why these water norms have changed over time, and whether such changes can be anticipated if not predicted. I did not question the odd sound of the duty of water expression at a time when societies were increasingly asking whether there were duties to water. Nor did I reflect upon why the word "duty" was used, or what connotations it has had, past and present? This paper strives to address these questions.

The duty of water concept is still used in some irrigated regions to establish basic standards of water use. An influential judicial opinion defined it as:

That measure of water which, by careful management and without wastage, is reasonably required to be applied to any given tract of land for such a period of time as may be adequate to produce therefrom a maximum amount of such crops as ordinarily are grown thereon (State of Colorado Supreme Court, 1954).

There are many interesting phrases in this definition: "careful management", "without wastage", "reasonably required", "adequate", "maximum amount", and "ordinarily grown". These terms have complex normative connotations as well as analytical significance. They refer to: 
- ordinary practices (i.e., normal water uses);

- standards (i.e., measurable expectations for normal water use practices);

- values (i.e., ascription of instrumental, inherent, and/or intrinsic water significance); and

- justifications (i.e., reasons for water values, standards, and practices).

Collectively, these normative dimensions of water use help compare observations with expectations. In addition to understanding how norms operate in specific places today, it is important to reconstruct how they have developed over time in ways that have shaped contemporary water problems. Approached in an historical way, water duties can be understood in dynamic terms, i.e., less in terms of established norms, and more in terms of emergent norms. The historical geography of water norms can help extend predictive explanation toward the social as well as hydrologic bases of water management.

\section{A socio-hydrologic framework for analysis}

Rather than treat social and hydrologic dimensions of water management separately, socio-hydrology strives to examine them jointly, as they are produced and experienced in the world. Socio-hydrology is thus an emerging field of water inquiry analogous to the field of eco-hydrology (e.g., Eagleson, 2005). It is defined by Sivapalan et al. (2012) as the co-evolution or co-production of water-society relationships in time and space. Co-evolution is characterized by emergent properties in social and hydrologic systems, the focus of which in this paper are emergent water norms (cf. Falkenmark and Folke, 2010; Gerlak et al., 2011).

Sivapalan et al. (2012) identified three main lines of sociohydrologic research: (1) historical; (2) comparative; and (3) process-focused. This paper pursues the first category of historical socio-hydrology, which offers a longitudinal perspective on changing water norms and thereby stimulates ideas about future water management alternatives. When approached critically, historical socio-hydrology can also complement and challenge other approaches to prediction, including scenario construction and water demand forecasting. Glantz (1988) referred to this as forecasting by analogy, in which societies construct analogies about possible futures and assess their preparedness to meet them (cf. Meyer et al., 1998; Wescoat, 1992). More radical challenges concentrate on the social dynamics of power relations, political struggles, and modes of production in socio-hydrologic systems (Bakker, 2010; Baviskar, 2007; Mustafa, 2013; Swyngedouw, 2004; Zeitoun, 2011). This paper strives to link the history of water norms with socio-hydrologic practices that have shaped them.

With this brief explication of the historical sociohydrologic approach, the next section traces the origins of the duty of water concept back to steam engine performance in late 18th century Britain. The paper follows its evolving application in canal irrigation in colonial India, the American West, and contemporary water ethics.

\section{Origins of the duty concept}

The concept of duty has an ancient history (Cicero, 1991), but as a measure of water-related efficiency it can be traced back to late 18th century steam engine technologies in Britain. James Watt used the term duty to compare his patented steam engine performances with competing engines for mine dewatering in Cornwall (Nuvolari and Verspagen, 2007). From Roman times mines had employed chains of buckets drawn by geared water-lifting technologies, later known in Europe as whims, horse gins, horse windlasses, or horse capstans for short lifts of meters to several tens of meters (Fraenkel, 1986; Moseley and Mahan, 1866, pp. 203204; Oleson, 1984; Schiøler, 1973).

In 1712, Thomas Newcomen invented an early steam engine, named after himself, for draining tin and copper mines in Cornwall (Andrew and Allen, 2009). It was not the first steam device, early visions of which can be traced back to Hero of Alexandria, but 18th century Britain was the context in which steam engines competed with animal-driven water lifting machines. The relative efficiency of early steam engine pumps in Britain was not quantitatively measured until James Watt and partner Mathew Boulton developed more efficient engines and ways of comparing them with other technologies. Watt developed the concept of horsepower to compare his steam engines with the horse capstan (Cleveland, 2007; on the definition of horsepower as the physical work a horse can do by turning a 12-foot radius shaft a rate of 2.4 rotations per minute with a force of 180 foot-pounds [ft-lbs], which Watt overestimated at about $33000 \mathrm{ft}$-lbs per minute).

To compare steam engines, Watt developed the concept of "duty" around $1776 \mathrm{CE}$, defining it as the amount of physical work performed by an engine, measured in ft-lbs lifted per bushel of coal burned (Nuvolari and Verspagen, 2007). A bushel of coal weighed approximately 94 pounds and was an expensive input, so much so that Watt charged steam engine purchasers one-third of their savings in coal costs compared with a Newcomen engine as their "due." The term duty thus applied both to the physical performance of the engine and to economic charges for the engine's reduced coal costs (Cardwell, 1993, 1994; Symons, 2003, App. 1).

Watt and partners were secretive about their innovations, but steam engine owners were not. They wanted comparative data on engine duties, and commissioned Joel Lean to publish Lean's Engine Reporter, which ran from 1811 through 1904 (Nuvolari and Verspagen, 2007). Comparative analysis of engine data recorded impressive gains in engine efficiency during the early to mid-19th century, from millions to tens of millions of ft-lbs per bushel. 
This earliest concept of duty focused on water-lifting. There were stray, sometimes figurative, references to water performing a duty, i.e., physical work, in early 19th century English and Scottish publications (e.g., a stream does its duty, Aikin, 1805). An 1852 article argued that steam engines would give irrigators in Britain a competitive advantage over countries that had lower labor costs (Johnson, 1852). However, there would be important differences between the duty concepts applied in irrigation as compared with the intensely competitive steam engine business in Britain. Some of the mechanistic physical reasoning would persist (e.g., Johnson et al., 1977). The norm in steam engine pumping period was to maximize physical and economic efficiency; irrigation norms were more complex.

\section{The duty of water in 19th century canal irrigation in India}

Irrigation is even more ancient than water lifting technologies (Steward, 1990). Pre-modern irrigation systems in South Asia included floodplain farming in large perennial river valleys; many types of well, tank, and check dam irrigation; and a few long-distance canals (for historical reviews see Agarwal and Narain, 1997; Hegewald, 2002; Mosse, 2003).

The duty of water concept was adapted for large canal irrigation systems that ran tens to hundreds of kilometers in length. The pre-colonial antecedents of these canals may be briefly described. The earliest documented large canal in north India was commissioned by Sultan Firoz Shah Tugluqh in the mid-14th century (Habib, 1999, p. 34). It diverted water from the Yamuna River north of Delhi to the towns of Hansi and Hissar in the southwest. After lapsing in periods of political instability, it was renovated by a provincial governor in the Mughal period around 1570-1571 CE. A half-century later it was renovated again by the Mughal ruler Shah Jahan, and a branch was extended approximately $120 \mathrm{~km}$ eastward to the new Mughal capital of Shahjahanabad (known today as Old Delhi) for urban and agricultural water supply. Two other large 17th century canals were constructed on the Ravi and Chenab rivers in the Punjab plains, and an 18th century canal was taken from the east bank of the Yamuna River. Court historians described the normative aims of these works as extending cultivation for the prosperity of subjects and rulers (ibid, 35-36). There were thus only a few precedents for the massive extension of large-scale canal irrigation systems that developed from the 19th century onward.

British irrigation schemes in India had tentative beginnings and mixed aims, with surprisingly limited connection to contemporary European advances in water and agricultural sciences. There was nothing comparable to Lean's Engine Reporter, and there were few references to irrigation in the colleges that trained officers for service in India at Haileybury, Addiscombe, and the Royal Indian Engineering College at Cooper's Hill. Nineteenth-century British administra- tion was still headquartered in humid Calcutta while Delhi and more drought prone regions belonged to the peripheral North Western Provinces.

As early as 1805, an entrepreneur proposed to reopen the West Jumna Canal above Delhi at his expense in return for the revenues it might yield, but the East India Company declined (Colvin, 1833; Baird Smith, 1852). Public sanction for canal repairs began in 1810 but had little to show on the ground until 1820, and even then with reportedly poor quality earthworks (Colvin, 1833). Increased staffing led by John Colvin and Robert Smith, an artist-engineer, contributed to large-scale surveys for irrigation development on the interfluve (doab) between the Ganges and Yamuna (Archer, 1972; Skempton, 2002, pp. 148-149). Colvin (1833) published one of the first wide-circulation reviews of the emerging aims of irrigation, emphasizing its general improvement of the country through abundant water for land reclamation. Writing in the mode of an engineer, he represented irrigation finance more as the avoidance of financial waste rather than as the generation of revenue. He discussed a wide list of canal uses in addition to irrigation, including waterpower, water supply, transport, fishing, and forest tree planting. In all of these discussions, however, Colvin did not mention the area of land irrigated, the amount of water used per unit of land, or concept of water duty. Aside from stray references, such as an 1835 piece in the Meerut Universal Magazine that estimated the quantity of water withdrawn from a well by a Persian wheel, there was little evidence of emergent standards of water use during the first third of the 19th century (Bayley, 1835).

This began to change after a horrific drought and famine in 1837-1838. The first major planning study for a Ganges Canal was completed in 1840 , which estimated that one cfs could irrigate 218 acres of land (i.e., 350 bighas in local units of measurement) (Cautley, 1841). An ambitious new engineering school was planned at the town of Roorkee by engineer Proby Cautley in 1841. It opened in 1848, located strategically at the headworks for the new Ganges Canal. Similarly grand plans were laid out for Punjab rivers by Richard Baird Smith (1849a), again using the water planning standard of 218 acres per cfs. Finally, a report titled Sketch of Mairwara by Lieutenant-Colonel C. J. Dixon (1850) referred explicitly to the "irrigative duty" of that region. Although Dixon's study did not have much impact on the field, its timing indicates that the duty of water concept developed in 1840s irrigation planning - a good half-century after its use in steam engine pumping.

The literature on irrigation in India then developed in rapid and impressive ways with early accounts in the Calcutta Review (Baird Smith, 1849b) and the North American Review (Norton, 1853). British engineers published detailed comparative studies of irrigation duties in India and southern Europe (Baird Smith, 1852; Scott-Moncrief, 1868). The East India Company created a Department of Public Works in 1854 which was responsible for major canal irrigation and issued annual reports about its achievements and challenges 
(Government of India, 1857). However, the Revolt of 1857 led to transfer of power from the East India Company to the Crown which, along with a famine in 1860-1861, marked a major shift toward public irrigation and further elaboration of the duty of water concept. In 1864, a report on the Ganges Canal used the duty of water standard for analytical and planning purposes (Crofton, 1864). Duties of water for different canal commands in India ranged from 170 to 528 acres per cfs diverted, depending upon canal losses, soil conditions, crop water requirements, and cultivation practices. Three years later, the duty of water concept was said to be well-known (Wilson, 1867).

Finally, Beresford (1875) explicitly compared the estimation of irrigation duty on the Ganges Canal with the calculation of steam engine duty, completing the chain of analysis that developed over the course of a century. The duty concept was thus not directly transferred from one socio-hydrologic context to another, but instead followed a slow multi-linear process. The emerging norms for irrigation were heterogeneous compared with steam engine efficiency. Of the dual colonial irrigation concerns with efficiency and waste, the latter was more salient in the writings of engineers, if not administrators (Gilmartin, 2003). The logic of these large irrigation duties in India was to spread water as extensively as possible, maximizing the area irrigated, which some have called protective irrigation (Jurriens et al., 1996). While this provided a measure of crop insurance against drought, it contributed to the predictable under-performance of deficit irrigation systems. Water-spreading aggravated scarcity in the tail-ends of unlined canals and watercourses (Bandaragoda and Rehman, 1995, p. 31). It may also have slowed the adoption of high value drought-sensitive horticultural crops.

Postcolonial irrigation historians have shed light on the normative contradictions and struggles between imperial science and the science of empire, and their consequences for environment and society (Gilmartin, 1994). It was a sociohydrologic system that conflated resource efficiency with revenue generation, elite cooptation, pacification, famine protection, territorial control, strategic positioning in international cotton markets, and the diverse interests of colonial engineers (Ali, 1988). Although employed as a planning standard for reclaiming vast tracts of land, the duty of water concept in India had limited value for administering water use standards at the farm or field levels, where a stateadministered time-based system of irrigation turns through fixed outlets prevailed. The duty of water concept thus had limited utility in Indian irrigation projects after the initial phase of canal command planning.

\section{Evolving water norms and duties in the western US}

The US followed irrigation development in British India with keen interest. The first detailed publication on the subject was by a literary scholar and art historian Charles Eliot Nor- ton (1853), editor of the North American Review. The duty of water became a focus of attention in 1873, however, as the State of California grappled with irrigation alternatives for its Central Valley (Davidson, 1876; Wescoat, 2001). The State of California Board of Commissioners (1874) published international comparative data on the subject, as did the State Engineer of California (1880). They contrasted the low, wasteful duty of water in California with higher standards in Australia, India, Italy, and Spain. Also in 1874, the pioneering conservationist and US Senator George Perkins Marsh published "Irrigation: Its Evils, the Remedies, and the Compensations", which was one of the first documents to link duty of water with social ethics.

Analytically, the duty of water became an important research topic in newly established state water research centers in public universities at the end of the 19th century. Professor Elwood Mead (1887) of the Colorado Agricultural College prepared a Report of Experimental Work in the Department of Physics and Engineering based on campus irrigation experiments. He then took a position as the first Territorial Engineer in Wyoming, which adopted a statewide duty of water of 70 acres per cfs (Mead, 1890). Mead (1903) further argued that the duty of water should be measured in acre-feet per acre (af/ac) in order to assess farm and field-scale performance, which became widespread practice in the western US. It extended the use of the duty of water concept from canal planning to water rights allocation and administration.

These norms drew upon international data, comparing and contrasting them with the wide range of conditions in the western states. The US Senate (1890) charged consuls around the world to provide information about irrigation practices, including the duty of water, and received detailed responses from countries on every continent, including India. The American Society of Civil Engineers published a major monograph on Irrigation in India by Herbert Wilson (18901891, p. 370) who wrote:

Though the conditions of government and people are so different in India from those in America, many useful examples and lessons may be drawn from the methods of administration and legislation practiced there, as well as from the financial success or failure that has attended the construction of their works.

While the duty of water standard in India was commonly 218 acres per cfs, in the western US duties ranged from 40 to 80 acres per cfs (Weil, 1911). Why this difference? Both areas aimed for maximum utilization, albeit in profoundly different ways. Canal irrigation in British India established a standard for the maximum area irrigable with a given flow of water. In the US the duty of water concept was applied in precisely the opposite way - i.e., as the minimum standard for private water rights appropriation and use. The socio-hydrologic aims of irrigation in the US were pursued through private property rights, which made intensive, rather than extensive, water use the norm for development. In the initial phase of development, intensification involved 
applying more water per unit of land, i.e., increasing productivity by increasing water inputs. Later there would be pressures to increase water use efficiency, i.e., increase the area irrigated and crop produced per unit of water. A California court recognized that the duty of water should increase over time - "What is beneficial use at one time may, because of changed conditions, become a waste of water at a later time" (State of California Supreme Court, 1935). Although in principle the duty of water could increase over time in the western states, that rarely occurred, in part because water rights are a form of property. Anything that might diminish the size of a presumed property right is resisted vigorously (even though legally one only owns as much water as one uses beneficially, without waste, and without injury to other water rights).

Interestingly, the first irrigation law treatises in the US surveyed irrigation laws in other countries but they did not mention the duty of water standard because they predated its adoption in the US (e.g., Kinney 1894). Later editions did discuss cases that used the duty of water as a standard for a water rights appropriation (e.g., Kinney 1912, 1592-1605). By the 1950s, however, courts recognized the declining significance of the duty of water as a scientific measure and standard of water use:

Although the expression "duty of water", in the opinions of some present-day scholarly hydrologists and technical engineers, may be outmoded, provincial, unscientific and otherwise objectionable, nevertheless it is a term well understood and accepted by every rancher and farmer who has had practical experience in the artificial irrigation of land for the production of crops. (State of Colorado Supreme Court, 1954).

The duty of water concept continues to be used to some degree. For example, the Soil Science Society of America website includes definitions in its glossary of terms, and it has been the subject of recently proposed legislation in New Mexico (State of New Mexico, 2011). However, these applications have been waning as the science, technology, and policy of crop water use efficiency become increasingly sophisticated. For example, irrigation application requirements decrease with water efficient technologies, such as drip irrigation, but they increase with double-cropping and adoption of high-value drought sensitive crops. As a technical standard, the duty of water has been largely superseded by finergrained measures of water use efficiency and productivity.

The duty of water has been guided by social values and justifications, as well as technical standards, over the past $150 \mathrm{yr}$. Values in colonial India differed from those of the western US. As public and private socio-hydrologies continue to evolve, what future might the concept of "duty" hold? I want to suggest that waning operational usage in irrigation opens up new opportunities for reconstructing the duty of water in ethical terms.

\section{From water use standards to ethical duties}

The relatively small field of water ethics has expanded considerably over the past decade with contributions from leading water policy scholars (e.g., Delli Priscoli et al., 2004; Liu et al., 2011; Llamas et al., 2009). However, many water ethics publications focus more on substantive issues than on ethical frameworks for addressing them. The literature on the human right to water offers a partial exception, as it has developed various philosophical arguments based on natural law, utilitarianism, and progressive development of international law (Murthy, 2013; Sultana and Loftus, 2012; Winkler, 2012). An edited collection on water ethics by Brown and Schmid (2006) surveys a range of positions from utilitarianism to communitarian, ecocentric, theocentric, and pragmatist ethics.

As noted in the introduction, these studies have arisen in an era concerned more with duties to water and to vulnerable social groups than with the duty of water. It is precisely this gap that I would like to address below. The 19th and 20th century documents discussed above put forward social and sometimes ethical justifications for water use standards and water rights. For example, justifications for water rights (i.e., property rights not human rights) have drawn upon theories of utility, labor, virtue, liberty, and just desserts (Becker, 1981). Water rights case law has articulated the social bases for appropriation, and correlative duties of ownership. What happens if we shift from an emphasis on water rights to water duties, both with respect to property and more broadly with respect to human and non-human rights to water?

Philosophies of duty are sometimes referred to as deontological or rule-based ethics, a major source for which is Kant's Metaphysics of Morals (1996). These are not duties inherited by social custom, associated with public service, or undertaken for some beneficial end, however virtuous or beautiful. Instead, Kant argued that the only perfect duties that have moral value are those that arise solely from a pure good will detached from any aim and without regard for consequences. Good will strives to identify maxims that one can will to become universal laws (i.e., a categorical imperative), for which individual moral actors must have freedom and autonomy. Kant insisted that humans treat other humans as ends in themselves, solely out of good will, and never merely as a means. Duties of this sort are sometimes evoked in communitarian ethics and institutions, though even in those contexts their instrumental value is often emphasized (Falkenmark, 2010). More altruistic communitarian ethics are sometimes criticized as idealist, romantic, or naïve. Kant's individualistic perfect duties stand as ideals, poles apart from the more mainstream utilitarian ethics that hinge upon the consequences of acts and rules.

Utilitarianism is an important branch of consequentialist ethics that evaluates actions by their effects, which are often weighed as costs and benefits. Utilitarian water ethics predominate in mainstream water resources economics and 
policy analysis (Brown and Schmid, 2006, 77-124). Water project evaluation methods and optimization models were developed in the mid-20th century to maximize the net benefits of alternative courses of action (Griffin, 2006). Challenges to this approach, both from within and outside utilitarian traditions, have led to more complex forms of multiobjective, multi-criteria modeling and benefit estimation. A pivotal debate in late 20th century US water policy pitted utilitarian advocates for the single criterion of net economic benefits against pluralists who supported the four criteria framework articulated in the "Principles and Standards for Planning Water and Related Land Uses" (US Water Resources Council, 1973).

The idealist and utilitarian approaches seem removed from the lived realities of socio-hydrologies where water users and uses jointly engage one another as interdependent means and ends in the world. Pragmatist water and environmental ethics offer a more interdependent approach to means-ends relationships in water use, and to the discernment of ethical duties based on experimentation, aesthetic experience, and democratic pluralism (Dewey, 2002; Katz and Light, 1996; Minteer, 2011; Wescoat Jr., 1992).

The pragmatist alternative may be briefly discussed in relation to the historical socio-hydrologies presented above. First, it would regard the mechanistic analysis of steam engine efficiencies that give no attention to human well-being as useful but extremely narrow. In the example of South Asian irrigation, it would strive to interpret and clarify the multiple justifications for colonial canal development in relation to their constitutive moral philosophies, which historian Eric Stokes (1969) described as paternalist, utilitarian, and evangelical.

It would point out that similarly diverse ethical positions existed in the US reclamation movement at the turn of the last century, with evangelicals arguing for reclamation in Biblical terms as 'making the desert rejoice and blossom as a rose,' utilitarians arguing for decision-making based on net social benefits, and conservationists warning against the moral hazards of irrigation (Isaiah 35:1; Lee, 1980; Smythe 1905). Conservationist George Perkins Marsh (1874, p. 4) argued that relations between capital and labor in irrigation, "... is really a moral rather than a financial problem". He believed that the relations between labor and resources were unsatisfactory in European irrigation, as they had led to land accumulation by a few and to dispossession and demoralization of small landholders. "Water rights are a constant source of gross injustice and endless litigation", which argues for a strong public role in irrigation (ibid., 5). Marsh wrote before the formal articulation of pragmatist ethics which supports William James' (1975) conception of pragmatism as a new word for some old ways of thinking. Late 19th and early 20th century debates about the moral philosophy of irrigation and environmental management have continued these multiple threads up to the present time (Wescoat Jr., 2000, 2013). Pragmatists are more likely to argue for anthropocen- tric instrumentalism and against ecocentric, natural rights (Minteer, 2011). Where might a 21 st century pragmatist philosophy of water duties lead; and in what ways might it entail extension, or rejection, of previous conceptions of duty?

\section{Anticipating the emergent duties of water}

Several responses to these questions have been anticipated in previous sections of the paper. The introduction contrasted the duty of water with duties to water. The plural yet patronizing and extractive aims of colonial irrigation were contrasted with struggles over the justifications for, and limits of, private property rights in water. Property rights were contrasted with human rights. These ethical debates involving property, persons, and environments have been framed in terms of rights that have corresponding duties. Following the central thread of the paper, this section inverts that approach by starting with duties and then considering rights that have or have not yet been associated with them.

\subsection{Duty of intensification}

The original concept of duty reviewed here involved steam engine efficiency. Subsequent duties focused on irrigation efficiency. There is enormous potential for further increases in water use efficiency and productivity - from technologies of sensing, monitoring, and control systems; to analyses of water footprints, supply chains, and virtual water trade; and reforms in water resource economics, regulation, and governance. These movements extend previous conceptions of water duty, but they must anticipate the pitfalls of intensification, which include environmental impacts such as pollutant concentration, third party water rights injuries, and increased aggregate water consumption (Scott, 2013). Even so, the duty to intensify water use, subject to important constraints, is advancing in all sectors and is central to conservation ethics (Minteer, 2011; Vickers, 2001, xv-xvii).

\subsection{Duty of equitable access, allocation, and use}

Advocacy for equitable water use has ancient roots and contemporary manifestations. Recent struggles for equity focus on deprivation by gender, race, class, caste, indigeneity, and location (e.g., tail-end canal users) (Baviskar, 2007). Some water access claims have been recognized in courts, e.g., first nation water rights. Even when successful, however, many allocations remain paper rights rather than wet water. They may be transformed into wet water through the exercise of social duties to ensure equitable access. Such duties are core functions of the state. Elite capture of state water administration can give rise to social movements, some of which are more effective, and thus more pragmatic, than others (Bakker, 2010; Bebbington, 2008). In general, these emergent norms extend, rather than reject, previous water duties. 
A major exception is the public trust doctrine, which has origins in Roman law and posits that the state has an inalienable trust responsibility on behalf of its citizens to ensure access and protection for submerged lands and analogous spaces (Wescoat, 2009). Public trust responsibilities cannot be squared with earlier duty of water standards, but they did not come into conflict until the "Mono Lake case" (Audobon Society v. Superior Court of Alpine County, 1983, 33 Cal.3d 419, 189 Cal.Rptr. 346; 658 P.2d 709), in which public trust duties trumped private water rights. Public trust doctrine cases in South Asia have further extended the geographic scope and social justification for public duties to water and related environmental resources (Wescoat, 2009).

\subsection{Duty to ensure safe water and sanitation}

There are growing movements to establish human rights to the safe water and sanitation necessary for human survival, dignity, respect, and equality (Murthy, 2013). These movements invoke multiple ethical theories from natural law to constitutional rights to life, livelihood, and development, and human rights law (Sultana and Loftus, 2012; Winkler, 2012). But some state and non-state actors still do not recognize a human right to water. Additionally, some of the societies that refuse to recognize a human right to water (e.g., Canada and the US) have achieved relatively high levels of equitable, low-cost, high-quality water provision in their municipal service areas. Recent historical research explains these accomplishments in terms of self-interested avoidance of fire and disease hazards, rather than as evidence of a civic or moral duty to fulfill basic water needs (Anderson, 1988). However, sustained provision of high-quality low-cost, high-pressure water without discrimination is often presented by water utilities as a public duty, and reinforced as such by legal judgments. This historical example raises the question of whether human rights to water may gain greater traction if framed as a key component of expanding bundles of social duties with respect to water, at multiple levels from the person to community, civil society, state, and global humanity (cf. Demsetz, 1967 for the influential theory of property as a bundle of rights). Duties to ensure safe sanitation also have rich, complex, and sometimes morally problematic histories (Harrison, 1994). Historical research on sanitation duties may help envision new types of sanitation rights as well.

\subsection{Duties to non-human beings}

Water rights for animals and environmental flows also have a mixed record of progress in theory and practice. Kant wrote of duties with regard to non-human beings, rather than duties to those creatures, by which he limited the possession of rights and duties to humans. In Islamic water law, by comparison, animals and humans have rights to take water necessary for their survival in principle, if not often in practice (Wescoat Jr., 1995). In the West animals have no inher- ent rights to water. However, most societies demand humane treatment of animals, which includes provision of water for domesticated animals, and water access for selected species (e.g., favored fish, streams, and endangered species). Even in these cases, however, ensuring water for non-human beings is a social duty, not an animal right. Duties to consider plant water needs are further out on the horizon, but certainly not beyond ethical imagination (Hall, 2009, 2011; Wescoat, 2013).

\section{The duty to re-balance the duties of water in socio-hydrologic systems}

The emergent duties discussed above build upon, and in some cases move beyond, the duties of water developed in Britain, India, and the US over two centuries. These emergent duties may be considered separately or jointly, with predictions made about their direction, scope, and pace of development. The public trust doctrine introduced above provides a good example. Taken separately, it articulates the duty of a state to fulfill its inalienable trust responsibility to manage submerged lands on behalf of the public. It dates back to Roman times but was rediscovered and applied along the Chicago lakefront in the 1890s and later to protect Mono Lake in California in the 1980s. Some predicted that it would advance rapidly as a new environmental norm that would radically limit private water rights. That did not happen in the US to anything like the extent anticipated, but US precedents have been highly influential in South Asia where further extensions of public duties seem likely (Wescoat, 2009).

Although emergent norms such as the public trust doctrine can be studied individually at one level, they develop in tandem with other values that shape, constrain, and interact with one another. As with the four criteria in the Principles and Standards for Planning Water and Related Land Uses, some argue that they can and must be reduced to one criterion to provide a consistent rational guide for public choice. Others argue that they cannot be reduced to one criterion; and that it is sounder in theory and practice to balance multiple criteria simultaneously.

The historical examples traced in this paper indicate that, with the exception of Watt's steam engine duty, the duty of water has always encompassed multiple measures, standards, values, and justifications. While not logically consistent or analytically precise, these changing duties of water embody diverse social and environmental aims. If this plural situation is not only an historical fact, but inherent in the life and thought of complex societies, it suggests that emergent water norms should be addressed jointly with a pragmatic pluralistic approach that continuously balances sociohydrologic principles, processes, and outcomes (see Pappas, 2008, 172-184 on balance in pragmatism ethics). Balancing is not merely an episodic weighing or aggregation of preferences for decision-making. It is a continuous democratic 
struggle to fulfill established and emergent duties, sustaining those that have enduring integrity and dropping others that prove deficient in utility or equity. While the outcome of such struggles cannot be predicted, this paper has shown that they can be more deeply understood in several key ways: first, socio-hydrology is useful for reconstructing the historical balancing of established and emergent water duties; second, understanding emergent water norms involves close attention to the linkages among measurement, standards, values, and justifications; and third, a pragmatic pluralistic approach has particular promise for shedding light on the normative dimensions of socio-hydrologic problems, processes, and prospects.

Acknowledgements. This paper has benefited from four discussion paper reviewers by David Gilmartin, Sharmila Murthy, Daanish Mustafa, and Robert Varady; and earlier verbal feedback at the Carr Center for Human Rights, Harvard Kennedy School of Government; University of Colorado-Boulder; Arid Lands Institute, Woodbury University; and American Academy for the Advancement of Science.

Edited by: V. Srinivasan

\section{References}

Agarwal, A. and Narain, S.: Dying Wisdom: Rise, Fall and Potential of India's Traditional Water Harvesting System, Center for Science and Environment, Delhi, 1997.

Aikin, A. (Ed.): Review of On the Landed Property of England by Mr. [William] Marshall, in: The Annual Review and History of Literature, III, 707, London: Longman, Hurst, Rees and Orme, 1805.

Ali, I.: Punjab Under Imperialism: 1885-1947, Oxford University Press, Delhi, 1988

Anderson, L.: Fire and disease: the development of water supply systems in New England, 1870-1900, in: Technology and the Rise of the Networked City in Europe and America, edited by: Tarr, J., Temple University Press, Philadelphia, 42-89, 1988.

Andrew, J. H. and Allen, J. S.: A confirmation of the location of the 1712 "Dudley Castle" Newcomen engine at Coneygree, Tipton, Int. J. Hist. Eng. Technol., 79, 174-182, 2009.

Archer, M.: An Artist Engineer: Colonel Robert Smith in India, 1805-1830, The Connoisseur, 79-88, 1972.

Baird Smith, R.: Agricultural Resources of the Punjab; Being a Memorandum on the Application of the Waste Waters of the Punjab to Purposes of Irrigation, London: Smith, Elder and Co., 1849a.

Baird Smith, R.: Canals of irrigation in the North-Western Provinces, Calcutta Review, 12, 79-183, 1849b.

Baird Smith, R.: Italian Irrigation, London: W.H. Allen \& Co., 1852.

Bakker, K.: Privatizing Water: Governance Failure and the World's Urban Water Crisis, Cornell Press, Ithaca, 2010.

Bandaragoda, O. J. and Rehman, S.: Warabandi in Pakistan's canal irrigation systems: Widening gap between theory and practice,
International Irrigation Management Institute, Country Paper, No.7, Colombo, Sri Lanka, 1995.

Baviskar, A. (Ed.): Waterscapes: The Cultural Politics of a Natural Resource, Permanent Black, Delhi, 2007.

Bayley, W. B.: On the amount of irrigation from wells in the northern dooab [sic], Meerut Universal Magazine, 427-428, 1835.

Bebbington, A. J.: Landscapes of possibility? Livelihood and intervention in the production of Andean landscapes, in: Political Economies of Landscape Change, edited by: Wescoat, J. and Johnston, D., Springer, Dordrecht, 51-76, 2008.

Becker, L.: Property Rights: Philosophical Foundations, Routledge, London, 1981.

Beresford, J. S.: Duty of water, Roorkee Institute Professional Papers no. 212, Roorkee, India, 1875.

Brown, P. and Schmid, J. (Eds.): Water Ethics: Foundational Readings for Students and Professionals, Island Press, Washington, DC, 2006.

Cardwell, D. S. L.: Steam engine theory in the nineteenth century: from duty to thermal efficiency; from Parkes to Sankey, The Newcomen Society, 65, 117-128, 1993-1994.

Cautley, P.: Report of the Central Doab Canal, Allahabad Mission Press, Allahabad, 1841.

Cicero, M.: On Duties (De Officiis), edited by: Griffin, M. T. and Atkins, E. M., Cambridge University Press, Cambridge, 1991.

Colvin, J.: on the restoration of the ancient canals in the Delhi territory, Jo. Asiatic Soc. Bengal, 2, 105-128, 1833.

Crofton, J.: Report on the Ganges Canal, Roorkee, 1864.

Cleveland, C. J.: Horsepower, Encyclopedia of Earth, available at: http://www.eoearth.org/article/Horsepower (last access: 28 September 2013), 2007.

Davidson, G.: Irrigation and reclamation of land for agricultural purposes, as now practiced in India, Egypt, Italy, etc., Exec. Doct 94, US Senate. 44th Cong. 1st Sess., 1876.

Delli, Priscoli J., Dooge, J. C. I., Llamas, R., and World Commission on the Ethics of Scientific Knowledge and Technology: Water and Ethics: Overview, UNESCO, Paris, 2004.

Demsetz, H.: Toward a theory of property rights, Am. Econ. Rev., 57, 347-359, 1967.

Dewey, J.: The Moral Writings of John Dewey, Rev. edited by: Gouinlock, J., Prometheus Books, Amherst, NY, 2002.

Dixon, C. J.: Sketch of Mairwara, Smith, Elder and Co., London, 1850.

Eagleson, P.: Ecohydrology: Darwinian Expression of Vegetation Form and Function, Cambridge University Press, Cambridge, 2005.

Falkenmark, M. and Folke, C.: Ecohydrosolidarity: a new ethics for stewardship, in: Water Ethics, edited by: Brown, P. and Schmidt, J., Island Press, Washington, 247-264, 2010.

Fraenkel, P. F.: Water-Lifting Devices, FAO Irrigation and Drainage Paper, 43, FAO, Rome, 1986.

Gerlak, A. K., Varady, R. G., Petit, O., and Haverland, A. C.: Hydrosolidarity and beyond: Can ethics and equity find a place in today's water resource management?, Water Int., 36, 251-265, 2011.

Gilmartin, D.: Scientific empire and imperial science: colonialism and irrigation technology in the Indus basin, J. Asian Studies, 53, 1127-1149, 1994. 
Gilmartin, D.: Water and waste: nature, productivity and colonialism in the Indus basin, Economic and Political Weekly, 48, 50575065, 2003.

Glantz, M. H. (Ed.): Societal Responses to Regional Climatic Change: Forecasting by Analogy, Westview, Boulder, 1988.

Government of India: Progress Reports of the Public Works Department, For the Year 1854-1855, Calcutta, 1857.

Griffin, R. C.: Water Resource Economics: The Analysis of Scarcity, Policies, and Projects, MIT Press, Cambridge, MA, 2006.

Habib, I.: The Agrarian System of Mughal India, 1556-1707, 2nd Rev. Oxford University Press, Delhi, 1999.

Hall, M.: Plant autonomy and human-plant ethics, Environmental Ethics, 31, 169-182, 2009.

Hall, M.: Plants as Persons: A Philosophical Botany, SUNY Press, Albany, 2011.

Harrison, M.: Public Health in British India: Anglo-Indian Preventive Medicine 1859-1914, Cambridge University Press, Cambridge, 1994.

Hegewald, J. A.: Water Architecture in South Asia: A Study of Types, Developments, and Meanings, E. J. Brill, Leiden, 2002.

James, W.: Pragmatism and the Meaning of Truth, Harvard University Press, Cambridge, MA, 1975.

Johnson, C.: Recent improvements in irrigation, The Farmer's Magazine, Rogerson and Tuxford, London, 3rd series, I,I, 69-73, 1852.

Johnson, S. H., Early, A. C., and Lowdermilk, M. K.: Water problems in the indus food machine, JAWRA J. Am. Water Resour. Assoc., 13, 1253-1268, 1977.

Jurriens, M., Mollinga, P., and Wester, P.: Scarcity by Design: Protective irrigation in India and Pakistan, International Institute for Land Reclamation and Improvement, Wageningen, the Netherlands, 1996.

Kant, I.: Metaphysics of Morals, edited by: Gregor, M., Cambridge University Press, Cambridge, 1996.

Katz, E. and Light, A. (Eds.): Environmental Pragmatism, Routledge, London, 1996.

Kinney, C. S.: Treatise on the Law of Irrigation and Water Rights, 1st Ed., Bender-Moss Company, San Francisco, 1894.

Kinney, C. S.: Treatise on the Law of Irrigation and Water Rights, 2nd Ed., Bender-Moss Company, San Francisco, 1912.

Lee, L. B.: Reclaiming the American West: A Historiography and Guide, ABC-Clio, Santa Barbara, 1980.

Liu, J., Dorjderem, A., Fu, J., Lei, X., Liu, H., Macer, D., Qiao, Q., Sun, A., Tachiyama, K., Yu, L., and Zheng, Y.: Water Ethics and Water Resource Management, UNESCO, Bangkok, 2011.

Llamas, M. R., Martìnez-Cortina, L., and Mukherji, A. (Eds.): Water Ethics, Marcelino Botiìn Foundation Water Workshop, CRC Press, Boca Raton, FL, 2009.

Marsh, G. P.: Irrigation: Its Evils, the Remedies, and the Compensations, 43rd Cong, 1st Sess., Senate Misc. Doc. 55, Washington, 1874

Mead, E.: Report of Experiments in Irrigation and Meteorology, Colorado Agricultural College, Fort Collins, 1887.

Mead, E.: Second Annual Report 1889, State Engineer, Laramie, Wyoming, 1890.

Mead, E.: Irrigation Institutions, Macmillan, New York, 1903.

Meyer, W. B., Butzer, K. W., Downing, T. E., Wenzel, G. W., Wescoat, J. L. Jr., and Turner II, B. L.: Reasoning by analogy, in:
Human Choice and Climate Change: Tools for Policy Analysis, edited by: Rayner, S. and Malone, E., Battelle Press, Columbus, 217-290, 1998.

Minteer, B.: Refounding Environmental Ethics: Pragmatism, Principle, and Practice, Temple University Press, Philadelphia, 2011.

Moseley, H. and Mahan, D. H.: The Mechanical Principals of Engineering and Architecture, John Wiley, New York, 1866.

Mosse, D.: The Rule of Water: Statecraft, Ecology, and Collective Action in South India, Oxford University Press, Delhi, 2003.

Murthy, S.: The human right(s) to water and sanitation: history, meaning and the controversy over privatization, Berkeley Journal of International Law, 31, 1 January 2013, available at:: http:// papers.ssrn.com/sol3/papers.cfm?abstract_id $\$=\$ 2195071,2013$.

Mustafa, D.: Water Resource Management in a Vulnerable World, I. B. Tauris, London, 2013.

Norton, C. E.: Canals of irrigation in India, North American Review, 77, 439-466, 1853.

Nuvolari, A. and Verspagen, B.: Lean's Engine Reporter and the development of the Cornish Engine: A reappraisal, Trans. Newcomen Soc., 77, 167-189, 2007.

Oleson, J. P.: Greek and Roman Mechanical Water-Lifting Devices: The History of a Technology, Springer, Dordrecht, 1984.

Pappas, G. F.: John Dewey's Ethics, Indiana University, Bloomington, 2008.

Schiøler, T.: Roman and Islamic Water-Lifting Wheels, Odense University, Copenhagen, 1973.

Scott, C.: Resource-use efficiency, once paradigm now paradox: The socio-hydrology of waste, Paper presented at the American Association for the Advancement of Science, Boston, available at: http://aaas.confex.com/aaas/2013/ webprogram/Paper9286.html, 2013.

Sivapalam, M., Savenije, H., and Blöschl, G.: Socio-hydrology: A new science of people and water, Hydrol. Process., 24, 1270-1276, 2012.

Scott-Moncreiff, C. C.: Irrigation in Southern Europe, E. \& F.N Spon, London, 1868.

Skempton, A.: Biographical Dictionary of Civil Engineers in Great Britain and Ireland, Vol. 1, 1500-1830, Thomas Telford, London, 2002.

Smythe, W. E.: The Conquest of Arid America, The Macmillan Company, New York, 1905.

State of California, State Engineer: Annual Report of the State Engineer to the Governor of the State of California, Sacramento, 1880.

State of California, Board of Commissioners: Report of the Board of Commissioners on the Irrigation of the San Joaquin, Sacramento, 1874

State of Colorado Supreme Court: Farmers Highline Canal \& Res Co. v. City of Golden, 272 p.2d 629, 129 Colo. 575, 1954.

State of New Mexico: An Act. Relating to water; amending a section of chapter 72 NMSA 1978 to provide for a single duty of water for all irrigated crops in a stream system, 50th Legislature, First session, House Bill 279, 2011.

Steward, J. (Ed.): Theory of Culture Change, University of Illinois Press, Urbana, 1990.

Stokes, E.: The English Utilitarians and India, Oxford University Press, Oxford, 1969.

Sultana, F. and Loftus, A. (Eds.): The Right to Water: Politics, Governance and Social Struggles, Earthscan, Abingdon, Oxon, 2012. 
Swyngedouw, E.: Social Power and the Urbanization of Water: Flows of Power, Oxford University Press, Oxford, 2004.

Symons, J. C.: The Mining and Smelting of Copper in England and Wales, 1760-1820, Masters thesis, Coventry University in collaboration with University College Worcester, 2003.

US Senate: 51st Cong. 1st Sess.: Report of the Special Committee of the United States Senate on the Irrigation and Reclamation of Arid Lands. Senate Report 928, part 5. Letter from R.J. Hinton to US consuls, 249-250, dated 23 April 1889, Government Printing Office, Washington, 1890.

US Water Resources Council. Principles and standards for planning water and related land resources. Water Resources Council, Washington, DC, 10 September, 1973.

Vickers, A.: Handbook of Water Use and Conservation, Waterplow, Amherst, MA, 2001.

Weil, S. C.: Water Rights in the Western States, 3rd Ed., 2 Vols., Bancroft-Whitney, San Francisco, 1911.

Wescoat Jr., J. L.: Common themes in the work of Gilbert White and John Dewey: A pragmatic appraisal, Annals of the Association of American Geographers, 82, 587-660, 1992.

Wescoat Jr., J. L.: The "right of thirst" for animals in Islamic water law: A comparative approach, Environment and Planning D: Society and Space, 13, 637-654, 1995.
Wescoat Jr., J. L.: Water rights in South Asia and the United States: Comparative perspectives, 1873-1996, in Land, Property and the Environment, edited by: Richards, J. F., ICS, Oakland, 298-337, 2001.

Wescoat, J. L.: Submerged landscapes: The public trust in urban environmental design, from Chicago to Karachi and back again, Vermont J. Environ. Law, 10, 435-475, 2009.

Wescoat Jr., J. L.: The "duties of water" with respect to planting: toward an ethics of irrigated landscapes, J. Landscape Archit., 8, 8-16, available at: http://www.tandfonline.com/doi/abs/10.1080/ 18626033.2013.864070\#preview, 2013.

Wilson, A.: Irrigation in India and in Spain: Institution of Civil Engineers and Clowes and Sons, London, 1867.

Wilson, H. M.: Irrigation in India, U.S.G.S. 12th Annual Report, Part II, Irrigation, Washington, 1890-1891.

Winkler, I.: Human Right to Water: Significance, Legal Status and Implications for Water Allocation, Hart Publishing, Oxford, 2012.

Zeitoun, M.: Power and Water in the Middle East: The Hidden Politics of the Palestinian-Israeli Water Conflict, I. B. Tauris, London, 2011. 